The Geneva Papers on Risk and Insurance, 23 (No. 87, April 1998), 265-293

\title{
The Applicability of the Principles of Private Insurance to Social Health Care Insurance, Seen from a Law and Economics Perspective*
}

\author{
by Michael G. Faure**
}

\section{Introduction}

This paper contributes to the current discussion about the reform of social insurance in Western Europe and more particularly health insurance, from a law and economics perspective. In many legal systems it is now felt that the health insurance schemes that were developed a few decades ago have come under increasing pressure ${ }^{1}$. The increasing costs of health care systems (and of social insurance in general) have led to a variety of proposals $^{2}$. In some legal systems it is noticeable that the government has progressively withdrawn from providing all-inclusive social insurance schemes and prefers to rely more

* I am grateful to Paul Fenn, Neil Rickman, Jacques Siegers and the participants in the joint conference between the EALE and the Geneva Association for useful comments on an earlier draft of this paper and to Cees Karregat for useful research assistance.

** Maastricht University, the Netherlands.

1 See with respect to the American health care reform debate some of the relevant insurance economics issues discussed by Aaron, H., "Issues Every Plan to Reform Health Care Financing must Confront", Journal of Economic Perspective, 1994, vol. 3, 31-43; Frank, R., "Lessons from the Great Battle: Health Care Reform, 1992-1994", Arch. Phys. Med. Rehabil, 1997, 120-124 and Pauly, M., "Taxation, Health Insurance and Market Failure in the Medical Economy", Journal of Economic Literature, 1986, 629-675: see also the recent survey by Newhouse, J., "Reimbursing Health Plans and Health Providers: Selection versus Efficiency in Production", Journal of Economic Literature, 1996, vol. 34, 1236-1263; see equally the discussion of this debate from a public finance perspective by Zeckhauser, R., "Public Finance Principles and National Health Care Reform", Journal of Economic Perspective, 1994, 55-60.

2 See Van Wijngaarden, P. and Van den Heuvel, F., "Privatisering sociale zekerheid ter discussie", Sociaal bestek, 1995, nr. 12, 2-6. 
heavily on market solutions and private insurance. This behaviour obviously fits with the deregulation wave that hit Western European politics in the 1980s.

As a consequence of this deregulation - for example in the Netherlands - an increasing use of the liability system is advocated, so that tort law could be used more often to compensate accident victims, thereby releasing the social security system from this heavy burden ${ }^{3}$. In that debate attention has also been paid to the role of private insurance as an alternative to social insurance. The question therefore arises of how to find a proper balance between the two systems.

These questions have already received a lot of attention, more specifically from economists interested in public finance and social security. The basic question addressed in that literature is how health care systems can be reformed in such a way that they still provide compensation for basic needs and yet remain financially affordable. The question of the efficiency of health care systems is obviously a very complex one which it would be impossible to address in a single paper. This paper attempts to add to the discussion modestly by looking at some of the central issues in health care reform from a law and economics angle. The approach used in this paper is not so much that of focusing on the economic analysis of social security law, but on differences and similarities between private and social insurance, since this question was precisely one of the central issues of the conference in Hamburg4. One of the advantages of the law and economics methodology is that existing legal structures can first be assumed away, simply asking the question of how an efficient health care system could be shaped. This can be done by asking what are the central questions that have to be addressed when such a system is formed. These questions will, as we indicated, be identified by using the principles of private insurance and examining whether these can be applied to social health care insurance or whether they would collide with such a system.

The basic questions in this respect are:

- Is it possible to structure social health care insurance in such a way that, just as in private insurance, the premium is related to the risk, i.e. bad risks are punished and good risks are rewarded?

- Is it feasible for the private insurance market to provide cover for health care costs now that deregulating governments seem to want to withdraw substantially from those activities and can private insurance be reconciled with the principles of social security?

This method allows us to show the tensions between private and social insurance as well as the limitations of applying private insurance principles to social insurance. This brief look at these potential tensions allows us to repeat some of the principles that underlie both systems. At the policy level it might be possible to show either how applying

\footnotetext{
${ }^{3}$ Although it has been argued that this evolution may put too heavy a burden on tort law as well; Faure, M. and Hartlief, T., "Towards an Expanding Enterprise Liability in Europe? How to Analyze the Scope of Liability of Industrial Operators and Their Insurers", Maastricht Journal of European and Comparative Law, 1996, 235-270.

${ }^{4}$ See also Mitchell, O. and Zeldes, S., Social Security Privatization: a Structure for Analysis, National Bureau of Economic Research, Working Paper 5512, Cambridge, 1996.
} 
private insurance principles to social insurance may lead to incentives for cost reduction or how private insurance can fill the gap caused by the deregulation of the social security system. Both questions fit in to what sociologists refer to as the trend to "decollectivisation" of the social security system 5 .

I should stress that it is not the goal of this paper to show that privatisation of health care compensation systems is desirable. The paper starts from the finding that at the policy level there is a demand for a shift to the private sector and then asks what the consequences of this shift would be, taking into account the different principles underlying both systems.

This paper will mainly address one aspect of social security, that of health care. The advantage is that this issue has often been dealt with in the literature. The analysis is to some extent also applicable to other forms of compensation, such as unemployment insurance ${ }^{6}$ or legal expenses insurance ${ }^{7}$.

The paper is set up as follows: first, we shall briefly address some of the main features of private insurance and social security (Section 2). Then we turn to the classic question of how moral hazard can be treated in a system of social insurance (Section 3 ). The next question to be addressed is the desirability of introducing compulsory insurance for health care (Section 4); then we address briefly the question of private market versus government provided insurance and the financing of health care insurance (Section 5). In addition, we look at the influence of the regulation of the providers of health care services on the price of the health care system (Section 6). Then we briefly summarize the findings of the law and economics literature (Section 7). Finally we shall pay attention to the legal boundaries that might play a part if one wished to reform the health care system according to principles of private insurance (Section 8). This is followed by comparing the results of the economic analysis with the legal analysis (Section 9). The paper finishes with a few concluding remarks (Section 10).

\section{Private insurance versus social insurance: basic principles}

Before addressing some of the features of private and social insurance in more detail, we shall briefly review the basic characteristics of both systems. Even this brief comparison will indicate how difficult it may be to apply principles of private insurance to social insurance schemes ${ }^{8}$.

Indeed, private insurance starts from the simple assumption that a demand for insurance arises from risk-averse individuals ${ }^{9}$. These risk-averse individuals demand

\footnotetext{
5 Van Wijngaarden, P. and Van den Heuvel, F., l.c., 2-6 and the recent dissertation by Vinke, H., Werknemerscompensatie bij beroepsgebonden schade, The Hague, SDU, 1997.

${ }^{6}$ Discussed, for example, by Fenn, P., "The Law and Economics of the Misconduct Rule of Unemployment Insurance", in Burrows, P. and Veljanovski, C.G., (eds.), The Economic Approach to Law, London, Butterworth, 1981, 307-319.

${ }^{7}$ See the paper by Fenn/Rickman, included in this volume.

${ }^{8}$ It is indeed not possible to give a lot of attention to these principles within the scope of this paper; we can merely point at a few of the most important characteristics.

${ }^{9}$ Risk aversion with respect to health care will be further discussed below, with respect to the question of compulsory insurance.
} 
insurance cover which is provided by insurers on competitive insurance markets. They aggregate similar but non-related risks into risk pools and are able to accept these risks because they can spread them over a large number of cases. To control moral hazard ${ }^{10}$ and adverse selection ${ }^{11}$ the insurer distinguishes risks according to the individual risk posed by the particular insured party. Hence, a system of risk differentiation is applied whereby narro'w risk pools are construed in such a way that the premium charged corresponds with the risk posed by the average insured in that particular pool. An important feature of private insurance is, hence, that the price charged, i.e. the premium, corresponds with the risk.

The insurer often charges a higher premium than the fair price. This depends upon his market position and upon the administrative costs. Depending upon the degree of risk aversion of the insured party and the premium charged, the individual demands insurance cover for specific risks to which he is averse.

Social security in general differs from the situation sketched above in many respects ${ }^{12}$. Health care is provided, at least as far as basic needs are concerned, either totally free of charge or with a modest deductible to almost all citizens. The legal systems may differ with respect to who can benefit from social security and with respect to the payment system. In some countries health care is simply provided for free; in other countries the patient must pay, but can recover the expenses from his insurer or, in other cases, the (social) insurer pays the costs of the health care system directly ${ }^{13}$. Within a social security system equal access to the health care system to a smaller or larger extent is usually essential. In addition, the price of social security is usually charged by withholding the premium from the wages of all employed workers. Some of the premium is therefore usually paid by the employed individual himself; in addition, the employer usually contributes substantially as well14.

In addition to withholding the premium at source, it should also be mentioned that the amount of premium to be paid for social security is generally income-dependent. Hence, although there may be large differences between countries, some essential features of health care systems as provided through social insurance seem to be consistent: contrary to the situation under private insurance, there is no risk differentiation, but a principle of solidarity between good and bad risks ${ }^{15}$. In addition, the premium is not dependent upon risk, but upon income.

\section{Moral hazard}

A central question, whether health care is provided through private insurance or via the government, is how an artificially high demand for health care can be avoided with

${ }^{10}$ See below 3.

11 See below 4.C.

12 Principles of social security are discussed by Pieters, D., Introduction into the Basic Principles of Social Security, Boston, Kluwer, 1993.

${ }^{13}$ The way the system is organized may be dependent upon the particular legal system. For an introduction to the social security system in Europe see Pieters, D., (ed.), Introduction into the Social Security Law of the Member States of the European Community, Antwerp, Maklu, 1993.

${ }^{14}$ From an economic perspective one can of course argue that in fact the employer's contribution to the premium is also charged to the employee in the form of reduced salary.

15 Also Mitchell, O. and Zeldes, S., o.c., 11 consider redistribution and national risk sharing as essential features of the social security system. 
insurance cover. Moral hazard is precisely the problem that the demand for a certain service (in this case health care) increases because the price for the service is reduced or eliminated. In a classic paper on moral hazard Arrow pointed out that the demand for health care increases as soon as full insurance cover is available ${ }^{16}$. Moral hazard does not occur only on the demand side. Given asymmetric information, the physician often determines what services and how much of them are needed. This may cause a moral hazard problem on the supply side as well, which we shall briefly discuss in Section 6 . Here we focus on the patient. The extent to which the moral hazard problem plays a role depends upon the elasticity of demand for the particular service. If demand is totally inelastic and hence not dependent upon the price level, there will be no moral hazard at all. If demand is, however, elastic, insurance cover will lead to a decrease in the marginal cost of medical care and hence a moral hazard emerges ${ }^{17}$.

\subsection{Risk differentiation}

The traditional answer is that there are basically two possible remedies for moral hazard: either the behaviour of the insured party is controlled by a corresponding adaptation of the premium or by partially exposing the insured party to risk, for example, through a deductible or through an upper limit on cover ${ }^{18}$. Considering the first potential remedy, advanced in traditional insurance economics, one might argue that there should be some link between the risk an insured party poses and the premium paid. In theory, this would mean that the more the health care system is used, the higher the premium should be. In insurance economics theory such an individual would then be classified as belonging to a high-risk group. Through such an individualisation of the risk, the insured party would then behave as if he were not insured at all and moral hazard would be avoided.

Observing the premium-setting practice of social security systems, it is immediately clear that the way premiums are charged in social security systems does usually not correspond with this traditional insurance economics answer to the moral hazard problem. First, the premium charged will usually be income dependent and not dependent upon the risk posed. Individual risk differentiation seems, therefore, impossible. Second, the idea of a strong differentiation of risks seems to collide with the idea of solidarity between good risks and bad risks which underlies many systems of social security ${ }^{19}$. In practice, risk differentiation would indeed mean that high-risk individuals would have to pay more premium than low-risk individuals. From a policy perspective the social security minister might not want to charge some individuals higher premium just because they had become ill. Moreover, the insurance economics idea of a risk-related premium seems to collide with the income redistributive goals of social security ${ }^{20}$.

16 Arrow, K., "Uncertainty and the Welfare Economics of Medical Care", American Economic Review, 1963, 941-973.

${ }^{17}$ See Pauly, M., "The Economics of Moral Hazard: Comment", American Economic Review, 1968, 531-537. 562 .

18 Shavell, S., "On Moral Hazard and Insurance", Quarterly Journal of Economics, 1979, 541-

${ }^{19}$ One example is the solidarity between younger employees and older patients, having to do with the fact that most health care expenditure is usually incurred in the final stage of a person's life.

20 Van Mierlo pointed out that the government in fact confusingly mixes two policy goals: guaranteeing equal access to health care with income redistribution (Van Mierlo, J.G.A., "Een alternatief voor het Plan-Simons? Overwegingen vanuit de welvaartstheorie", ESB, 1991, 1164). 
The question of course arises whether this conflict between the insurance economics need of risk differentiation to control moral hazard, on the one hand, and solidarity between good risks and bad risks in social security, on the other hand, leads to insurmountable problems. The problem is obviously not that persons who get ill rely on the (private or social) health care system; the problem is more that some people might be inclined to visit their general practitioner too often or purchase too much medicine if this can be obtained at no cost. To answer the question of whether there is a serious moral hazard problem, it is useful to distinguish between small and large risks. For large risks, such as surgery, the price elasticity of demand might be small. It is unlikely that anyone wants surgery just for fun; one can, therefore, assume the number of operations would not increase drastically from the moment that the price fell ${ }^{21}$. This might be different in the case of visits to a general practitioner or the purchase of medicine. For these kinds of health care services the price might well have an influence on the demand for the particular service ${ }^{22}$. A similar distinction between small and large risks can also be made as far as the moral hazard problem is concerned. No one will be inclined, for example, to have his leg amputated just because the operation is free. The fact that no distinction is made between low-risk and high-risk individuals does not, therefore, seem to be a problem as far as these large risks are concerned. The contrary might be true for small risks. For them it seems important to adapt the premium to the individual risk.

\subsection{Exposing the insured party to risk}

This brings us to a second potential control of moral hazard, partially exposing the insured party to risk. Introducing an upper limit on cover does not seem to be an efficient remedy, given the insolvency problem, which might lead to free-riding. Moral hazard can be controlled, however, more particularly as far as small risks are concerned, for example, through a deductible. The elasticity of demand for, say, a visit to a general practitioner, might well be rather large. If that were the case, moral hazard could be controlled through the introduction of a deductible ${ }^{23}$.

If one has to choose between the two ways of controlling moral hazard, adapting the premium to the individual behaviour of the insured party or partially exposing the insured party to risk, one should be aware of the fact that partially exposing the insured party to risk, for example with a deductible, obviously involves less information costs than detailed control of the behaviour of the insured party. Detailed control of the behaviour of the insured party with corresponding risk differentiation could also collide with solidarity between bad and good risks, required in social security. Even for smaller risks it might be relatively harsh to charge, say, the elderly, who might need more medication and more

\footnotetext{
21 This might, however, be different for "cosmetic" surgery such as breast-enlargements, etc. These "beauty corrections" can be regarded as a marketable item, so Kerkhoff, A.H.M., "The Physicians' Fraternity: Safeguard for Quality or Cartel?", in Gunning-Schepers, L.J., Kronjee, G.J. and Spasoff, R.A., (eds.), Fundamental Questions About the Future of Health Care, The Hague, Netherlands Scientific Council for Government Policy, 1996, 117.

${ }^{22}$ Below we indicate that this could be an argument in favour of compulsory (or social) insurance for larger risks, but private market insurance for smaller risks.

${ }^{23}$ Pauly, M., 1.c., 534-545 and Ehrlich, J. and Becker, G., "Market Insurance, Self Insurance, and Self Protection", Journal of Political Economy, 1972, 623-648.
} 
visits to a general practitioner, a higher premium than is charged to healthier, younger individuals. Imposing a deductible on good risks and bad risks can deter some inefficient overdemand and at the same time avoid the harshest effects of strict differentiation between bad and good risks. Moreover, even with a social security system with premiums dependent on incomes, demand can be modified by imposing a deductible as far as the low risks are concerned. There is, therefore, an increasing tendency in many Western European systems to introduce deductibles into the social security system. If they are introduced for services for which the demand depends on the price, this tendency can be supported from an economic point of view ${ }^{24}$. Obviously a deductible could be an appropriate instrument to provide incentives against an overdemand for health care services $^{25}$. One should, however, be careful that this is only used in the case of risks where the high level of demand is indeed an issue. Too high a deductible might have an adverse effect of overdeterrence, leading individuals who should see a general practitioner to the wrong decision in order to avoid a visit, and this might in the end lead to much higher costs (of, for example, hospital treatment) for the total health care system. Hence, one must be careful, even with imposing a deductible to avoid overdeterrence ${ }^{26}$.

\section{Compulsory insurance?}

One question that a regulator has to address is whether it is desirable to introduce compulsory insurance for health care costs and, if so, for what type of services. In private insurance theory one would generally argue that the answer to that question is dependent upon a lot of factors, among which are the degree of risk aversion of the consumers of the insurance product, concerning the specific risk and the elasticity of demand for medical care $^{27}$.

\subsection{The expected utility hypothesis}

In this approach we apply the classic utilitarian approach to insurance, claiming that insurance will increase the expected utility of risk-averse individuals ${ }^{28}$. This risk-aversion

${ }^{24} \mathrm{See}$, on this increasing debate on the promotion of preventative health care, the contributions in Van Wijngaarden, P.J., Van den Heuvel, F.G. and Vrooman, J.C. (eds.), Preventie in de sociale zekerheid, Den Haag, VUGA, 1992 and in Van Steenberge, J., Klosse, S. and De Leede, L.J.M. (eds.), Preventie: een solide basis voor sociale zekerheid?, Antwerpen, Maklu, 1994.

25 Whinston, M., "Moral Hazard, Adverse Selection and the Optimal Provision of Social Insurance", Journal of Public Economics, 1983, 49-71.

${ }^{26}$ See on possible conflicts between optimal incentives for prevention and optimal risk spreading Zeckhauser, R., "Medical Insurance: a Case Study of the Trade-off Between Risk Spreading and Appropriate Incentives", Journal of Economic Theory, 1970, 2, 10-26.

27 The question of what kind of circumstances and what kind of risks warrant the introduction of compulsory (liability) insurance has, among others, been analysed by Faure, M. and Van den Bergh, R., "Compulsory Insurance for Professional Liability", The Geneva Papers on Risk and Insurance, $1989,308-330$ and by Faure, M. and Van den Bergh, R., "Invloed van verzekering op de civiele aansprakelijkheid: een rechtseconomische analyse", in De invloed van verzekering op de civiele aansprake-lijkheid, preadviezen uitgebracht voor de vereniging voor burgerlijk recht, Lelystad, Vermande, 1990, 9-53.

${ }^{28}$ See, on this expected utility hypothesis, as an explanation of demand for insurance, the classic papers by Arrow, K., Aspects of the Theory of Risk-Bearing, Helsinki, Yrjö Johnsonin Säätiö, 1965 and Borch, K., "The Utility Concept Ap-plied to the Theory of Insurance", The Astin Bulletin, Vol. 1, $1961,245-255$. 
theory predicts that risk aversion is likely to be high for risks with a relatively low probability of occurrence, but with a high potential magnitude. Applied to health care this would mean that consumers' risk aversion would be greatest with respect to low probability risks with a high magnitude of damage, such as surgery or hospitalization. In addition, insurance theory holds that the degree of risk aversion will depend upon the wealth of the individual. A low-income individual may therefore be presumed to already have an aversion to the risk of paying his general practitioner, and may be extremely averse to the risk of having to pay a hospital bill. A Rockefeller, by contrast, may be risk neutral as far as the bill of his general practitioner is concerned and is probably only slightly risk averse to hospital bills. The situation of an average citizen may be somewhere in the middle; he may be rather risk neutral as far as the bills of the general practitioner are concerned, but risk averse towards hospital bills.

These notions are helpful if one asks whether health care insurance should be made compulsory or not. One way to approach this problem is to ask whether an average consumer would demand insurance against the particular risk if he were fully informed concerning the risk and the possibilities of insurance. In other words, would insurance increase his expected utility? If the conclusion is that insurance in this particular case would indeed increase the expected utility of the particular consumer, one could argue that compulsory insurance would be beneficial, since on average consumers would benefit from insurance cover. However, if it appears that individuals are perfectly informed of the risk and availability of insurance or that insurance for the particular risk and the specific individual would not increase the expected utility (perhaps because the particular consumer may be risk neutral towards the specific risk), introducing a duty to insure would only involve administrative costs without a compensating benefit.

Turning back to our previous discussion of the demand for health care one could tentatively state that it may be desirable to make a distinction between, on the one hand, relatively small risks (such as the general practitioner's bill and relatively cheap medicine) and larger risks, on the other hand, such as hospital bills and the more expensive medicines. Assuming that an average citizen might be relatively risk-neutral as far as these small risks are concerned, there may not be an argument for introducing compulsory insurance for those risks. One should in this respect also take into account the fact that even in a case of risk aversion the demand for insurance will also depend upon the premium charged. If the premium charged far exceeds the actuarially fair premium (because of high administrative costs and/or monopolistic price setting) the particular individual might not demand insurance in those particular circumstances. Compulsory insurance for those smaller risks would thus lead to inefficient results. Compulsory insurance may, however, be highly useful for those larger risks where, on average, consumers would anyway demand insurance. This reasoning obviously does not mean that there should be no insurance for these so-called smaller risks. But the case for regulation in the form of a duty to insure is less convincing there. For these smaller risks individuals could purchase insurance fitting their particular demand for coverage 29 .

\footnotetext{
${ }^{29}$ See, on supplemental health insurance, Garrat, R. and Marshall, J., "Supplemental Health Insurance", in Heremans, D. and Cousy, H., (eds.), Essays in Law and Economics III, Financial Markets and Insurance, Antwerp, Maklu, 1996, 225-241.
} 
If one therefore accepts that risk aversion may depend upon the nature of the risks, this means that there is no case for a generalized duty to insure against all possible health risks, but only to differentiate this duty according to the nature of the risk and the corresponding degree of risk aversion.

\subsection{Imperfect information}

The question, however, arises why there is a need for regulatory intervention if consumers are perfectly informed about risk. The answer is that the assumption we made that risk-averse individuals will make a careful analysis of their demand for insurance, depending upon their attitude towards risk and the information on the risk, may not be applicable for many of the population. If it appears that a particular citizen would not take insurance cover only because he lacks adequate information, this could be an argument in favour of compulsory insurance. Regulation in the form of making the purchase of insurance compulsory can then be seen as a classic correction of a market failure ${ }^{30}$.

However, imperfect information does not necessarily matter to the same extent for all risks. A distinction between small and large risks, as discussed above, could be useful in that respect. Information may be more particularly lacking about larger risks, such as hospital treatment. Consumers may underestimate the risk that they may be hospitalized and the corresponding cost in a systematic way. This lack of information may therefore play a role at least in the case of large risks, which justifies the introduction of compulsory insurance.

\subsection{Insolvency and transaction costs}

Building upon the previous point, another argument in favour of compulsory insurance can be made. We indicated above that, especially with risks which have a low probability of occurring but a high potential magnitude, there may be systematic underestimation of the risk.

This could lead to underinsurance and, in case of insolvency, these individuals would probably demand state-provided health care and thus free ride on the (insured) tax payer. This risk of free riding obviously plays a role in the case of insolvency. In that case compulsory insurance might provide better results, not only for the larger risks, such as hospital bills, but probably also for the risks that we consider to be smaller, such as the general practitioner's bills.

The major advantage of compulsory insurance in this particular context is that it also removes the necessity for the general practitioner to examine ex ante the solvency of his clients. Hence, one could argue that the knowledge that everyone has insurance cover reduces transaction costs. Skogh has powerfully argued that the expected utility hypothesis just provides a partial explanation of the demand for insurance; in his transaction cost

${ }^{30}$ See generally on the inadequacy of information as a criterion for regulation, Schwartz, A. and Wilde, L., "Intervening in Markets on the Basis of Imperfect Information: a Legal and Economic Analy-sis", University of Pennsylvania Law Review, 1979, 630-682 and Mackaay, E., Economics of Information and the Law, Boston, Kluwer, 1982. 
theory of insurance, Skogh argues that the most important function of insurance is the reduction of transaction costs ${ }^{31}$.

\subsection{Adverse selection}

A further point to consider in relation to the desirability of compulsory insurance is the adverse selection problem. In health insurance adverse selection plays an important role in the most literal sense that insurance will always be most attractive for the individuals who constitute the highest risk. If the insurer is not able to distinguish who these high risk individuals are, the adverse selection problem will emerge. Elderly people or persons who are aware of the fact that they will have a high level of demand for health care, have a relatively high demand for full insurance cover. Here the classic problem of asymmetric information arises ${ }^{32}$. Indeed, the individual who demands insurance generally possesses better information on his health and his future demand for health care than the insurer ${ }^{33}$.

Compulsory insurance could be proposed as a remedy for the adverse selection problem. This would mean that good risks as well as bad risks are forced to accept insurance cover; at least it avoids the insurer getting stuck with only the bad risks, which could lead him to a policy of not accepting some risks at all for insurance cover. Some Dutch experts in social security therefore propose a duty on the insurer to accept all proposals as a remedy to the adverse selection problem ${ }^{34}$. Obviously, this could also be considered an example of "forced solidarity" between good and bad risks. Though it cures the adverse selection problem, it obviously has the disadvantage that the good risks will be forced to take insurance cover which they do not demand, which could cause a considerable welfare loss. In addition, a mere duty to accept good and bad risks, without a possibility of risk differentiation, would dilute any incentive to control moral hazard, which could in the end have the perverse effect of increasing premiums, increased risk and perhaps uninsurability. Indeed, so far systems with a duty to accept insured parties without a possibility of risk differentiation have not proven very efficient. Hence, one should look for other devices than compulsory insurance to cure adverse selection, especially as far as the smaller risks are concerned. It should be possible to differentiate risks ex ante, for example through a medical check before accepting a particular insured party. This type of risk differentiation may well cure adverse selection without the need to introduce compulsory insurance where this might only have perverse effects.

\footnotetext{
${ }^{31}$ Skogh, G., "The Transactions Cost Theory of Insurance: Contracting Impediments and Costs", Journal of Risk and Insurance, 1989, 726-732.

32 Akerlof, G., "The Market for "Lemons": Quality, Uncertainty and the Market Mechanism", Quarterly Journal of Economics, 1970, 488-500.

${ }^{33}$ Akerlof precisely provides an example of adverse selection, pointing out that in the end elderly people might not be able to get health insurance on the private market any longer (Akerlof, G., l.c., 492-494).

${ }^{34}$ De Kam also proposes a duty to accept for the insurer as a remedy to the adverse selection problem (De Kam, C.A., "Privatisering van sociale zekerheid: een werkbaar alternatief?" in Fase, W.J.P.M., e.a., Sociale zekerheid: privaat of publiek?, Deventer, Kluwer, 1994, (36), 48) and Fase, W.J.P.M., "Privatisering of toch maar aanpassen?", in Fase, W.J.P.M., e.a., Sociale zekerheid: privaat of publiek?, Deventer, Kluwer, 1994, (86), 87.
} 


\section{Health care insurance via the private market or government provision?}

\subsection{Private insurers versus bureaucracies}

Once the previous question whether there is a case for compulsory insurance for some health-related risks has been answered, the question arises whether (compulsory) health care insurance should be provided through the private market or by the government. In this respect one could distinguish between social insurance which is, in most Western European systems, provided by government intervention, and private insurance provided by insurance companies operating in a competitive market. Although the social security systems in Western Europe are very generous (largely for historical and political reasons) in that respect, some systems seem, once more, to have made the traditional distinction, which we discussed before, between smaller risks and larger risks. Apparently, for example in Belgium for self-employed workers, larger risks are covered via government-provided social insurance whereas smaller risks can be covered on the private insurance market. Moreover, this social insurance is generally compulsory whereas private insurance for smaller risks is optional. However, this need not necessarily be the case. In some countries, for instance in the Netherlands, low-income groups can purchase additional insurance for the smaller risks via (government financed) health care funds.

On the choice between government-provided or private market insurance, an economist would usually refer to the theory of bureaucracies to argue that governmentowned operations that are not exposed to competitive pressures have little incentive for efficient production and might therefore be more expensive than private insurance companies providing the same product ${ }^{35}$. Generally, one could therefore argue that insurance cover could be provided by the private market, even if it were to be decided that these risks should be subject to compulsory insurance ${ }^{36}$. There are indeed many examples of compulsory insurance where the cover is not provided through social insurance or government-owned institutions but through private insurance companies. This, however, assumes that private insurance markets are sufficiently competitive. In that case insurance theory predicts that a diversified supply of different insurance policies will be provided at competitive premiums. Only if the private insurance market were not capable of covering certain risks or would provide inefficient results, for example because of a high degree of market concentration, is there an argument for government intervention ${ }^{37}$. Another argument in favour of government intervention could be that certain risks could be uninsurable on the private market, say, because of an incurable problem of adverse

\footnotetext{
${ }^{35}$ See generally Ferejohn, J. and Shipan, Ch., "Congressional Influence on Bureaucracy", Journal of Law, Economics \& Organization, Vol. 6, 1990,1-20.

${ }^{36}$ Also the Netherlands Scientific Council for Government Policy argued in a 1994 report "Belang en beleid" (Interest and Policy) that the public sector lacks the incentive which the private sector has to reduce the volume of health care costs (sce Dijkshoorn, M.W., "Ontwikkelingen in de WAO", Verzekeringsarchief, 1996, 82-86).

${ }^{37} \mathrm{See}$, on the negative consequences of restrictions on competition on the insurance market, Faure, M. and Van den Bergh, R., "Het toelaten van kartels op de Europese verzekeringsmarkt: hogere premies, lagere kwaliteit en meer ongevallen?", NJB, 1993, 261-267 and Faure, M. and Van den Bergh, R., "Restrictions of Competiti-on on Insurance Markets and the Applicability of EEC Antitrust Law", Kyklos, 1995, 65-85; and, with respect to health care insurance, Pauly, M., "Competition in Health Insurance Markets", Law and Contemporary Problems, 1988, 237-271.
} 
selection. If the government could gather information on the risk at lower costs than insurance companies, this would be an argument for government provided insurance ${ }^{38}$.

This shows that, in arguing that private insurers are in principle better than bureaucratic institutions at providing cover at competitive premiums, there is a strong case for private health care insurance, even if the provision of insurance should, for reasons mentioned above, in some cases be made compulsory. However, the flipside of introducing compulsory insurance is that the policy maker becomes dependent upon the private insurance market to insure the risks. As long as the market is competitive and sufficient cover is provided, this should not in itself be a problem. However, some risks might be uninsurable on the private market. One could, therefore, argue that they should not be insured at all, but in that case there could be suboptimal results because of the free-rider problem, since these people would be treated anyway in public hospitals. Hence, even for compulsory insurance provided by the private market, there might be a case for the government to provide insurance for those categories that could not obtain insurance cover on the regular market ${ }^{39}$. Obviously, providing such cover for people who could not otherwise obtain insurance is not the same as providing a general social insurance scheme. In addition, even if the government intervenes to provide cover for this remaining category, risks should be differentiated as much as possible within this category for the reasons mentioned above.

So far we have considered the choice between insurance via the private market or government provision, assuming that health care insurance can be provided via the private market, with risk-based premiums, taking into account general principles of insurance, more specifically risk differentiation. From this point of view we have argued that government intervention is not necessary as long as insurance is provided in a competitive market and that moral hazard as well as adverse selection can be controlled. The problem is, once more, that social security policy apparently often aims at income redistribution as well. Therefore social security schemes premiums are often not risk based, but income dependent. This inevitably collides with the insurance principle that the premium should correspond with the real risk; this income redistributive goal can probably only be realised through government intervention. Leaving this redistributive goal aside, there are fewer arguments for health care insurance via the government than via the private market. From this it follows that the question of whether government intervention is necessary can only be answered when the aim of social security policy has been clarified. This choice inevitably incorporates a normative element. If income redistribution is considered to be the aim of social security, it is obviously not possible to accomplish risk differentiation at the same time.

\subsection{Financing health care schemes}

A political hot issue, closely connected to the choice between the private market and regulation, is obviously the way a health care scheme should be financed. Within a classic

38 So Johnson, W., "Choice of Compulsory Isurance under Adverse Selection", Public Choice, 1977, 23-25; Pauly, M., "Overinsurance and the Public Provision of Insurance: The Roles of Moral Hazard and Adverse Selection", Quarterly Journal of Economics, 1974, 44-62 and Rothschild, M. and Stiglitz, J., "Equilibrium in Competitive Insurance Markets: an Essay on the Economics of Imperfect Information", Quarterly Journal of Economics, 1976, 629-649.

${ }^{39} \mathrm{See}$, for example, on the Medicaid system in the US, Van de Griendt, W., "De Amerikaanse paradox", Sociaal bestek, 1995 (7/8), 9-12 and Frank, R., 1.c., 122-123. 
model of private insurance the answer is relatively simple. In that case, a risk-averse consumer will purchase (by choice or compulsorily) health care insurance from a competitive insurance market and pay a corresponding premium, related to his demand for insurance and related to the individual risk he poses. Essential to private insurance is the fact that the premiums charged must correspond to the risk, not only to control moral hazard, but also to guarantee that funds will be available when the insured risk manifests itself. The premiums paid will in principle be reserved to account for future risks. An insurer is under a contractual obligation to fulfil his contractual duties vis- $\grave{a}$-vis his insured party. Hence, he will have to bear the consequences of bad risk calculations that bring him into trouble afterwards himself. A private insurer in principle does not have the possibility, say, of lowering the compensation due to the insured party or of increasing premiums for all existing insured parties ${ }^{40}$. The final consequence of bad calculations may be the traditional market sanction of bankruptcy.

Cover under social insurance basically comes from a different angle. Social security systems, as they have been developed since Bismark's initiative in the late 19th century assume that a minimum of social services, including health care, is delivered to those who could not afford to purchase insurance cover themselves. Again, this cover for lowincome classes, which may be deemed necessary from a policy perspective, could be provided if the government, for example, provides the cover itself for this remaining category. However, in many cases the principle of solidarity between good risks and bad risks will lead to income-depen-dent premium setting. This then inevitably leads to the question of whether such income-dependent premium setting can be reconciled with the insurance economics goal of avoiding moral hazard. As we indicated above, this may be problematic.

Unlike private insurers, the government providing the social insurance is not under a contractual duty to compensate the insured fully. Since the income of the social health care system is not risk related, there is a chance that at some moment the amounts reserved may not be sufficient to pay for the health care scheme. In that case, no bankruptcy follows but the government may either lower the payments due (through regulatory intervention) or look for additional sources of funding (say, from general income tax revenues). This shows the basic difference between the finance of private and social insurance schemes. An important consequence is that the shift from social to private insurance would not necessarily be negative for the insured; the government can always reduce the social insurance benefits unexpectedly because of budget constraints, whereas an insurer is bound to his contractual duties ${ }^{42}$. Some scholars indeed argue that a shift to a privatized system has the advantage for the insured parties of reducing political risk $^{43}$.

40) If an insurer did so, he would be in a disadvantageous competitive position.

${ }^{41}$ See Le Blanc, L.J.C.M., "Bismarck als benchmark. Enkele rechtseconomische beschouwingen over publie-ke sector en sociale zekerheid in Nederland", Ars Aequi, 1990, 654-659 and Fuchs, V., "From Bismarck to Woodcock: the "Irrational" Pursuit of National Health Insurance", Journal of Law and Economics, 1976, 347-359.

${ }^{42}$ So Dijkshoorn, M.W., l.c., 86.

${ }^{43}$ Mitchell, O. and Zeldes, S., o.c., 11. 


\section{Regulation of the providers of care}

So far we have advanced just a few legal and economic principles, applying basic insurance economics to health care issues. One of the aims was to investigate whether the application of these private insurance principles could be useful in countering the dangerous increase in health care costs. This problem was merely addressed by focusing on the incentives for the consumers of health care and their insurers or other sponsors of health care. One should, however, also address the incentives of the providers of health care, who will receive payments from private insurers or social insurance systems. The financial scheme should be designed in such a way that the providers of care still have incentives to reduce costs. The total cost of a health care system is obviously not only dependent upon the demand for health care, but also upon the supply side.

The supply of health care is often heavily regulated. In some cases health care providers such as general practitioners or surgeons are subjected to self-regulation by the medical profession. The possible negative effects of those (self-)regulatory schemes on the efficiency of the health care system have been analysed in law and economics research ${ }^{44}$. Several examples can be found in the literature and practice of oversupply of health care services. Den Hertog for instance points to the fact that medical specialists will too often prescribe a laboratory analysis for diagnosing for the simple reason that the fee awarded to the specialist is higher in that case than it would be for a simple examination ${ }^{45}$. This proves that the health care system should take into account the fact that providers of care can be subject to a moral hazard problem ${ }^{46}$. This has led, for example, Belgian policy makers to put a financial cap on the amounts paid out by the so-called free hospital insurance scheme after it had been established that physicians charged much higher fees if full insurance cover was available.

A problem in that respect is that the regulator who is responsible for financing a health care system can often only marginally control and remedy this problem of oversupply. An essential component of the relationship between the patient and the provider of care is asymmetrical information. This, by the way, is also advanced as the main reason for regulating professional services in the first place. Asymmetrical information means in practice that the provider of care has much better information on the optimal care to be provided in the specific case than the consumer. The particular treatment will often be chosen by the provider of the care, i.e. the physician, and not by the patient. In this respect we refer to the discussion of moral hazard, where it was mentioned that full insurance cover leads to an increased demand for medical services which have price-elastic demand. We have now indicated an additional problem: namely,

${ }^{44}$ Faure, M., Finsinger, J., Siegers, J. and Van den Bergh, R. (eds.), Regulations of Professions. A Law and Economics Approach to the Regulation of Attorneys and Physicians in the US, Belgium, the Netherlands, Germany and the U.K., Antwerp, Maklu, 1993.

${ }^{45}$ Den Hertog, J., "An Economic Analysis of the (Self-)Regulation of Physicians in the Netherlands", in Faure, M., Finsinger, J., Siegers, J. en Van den Bergh, R. (eds.), Regulation of Professions. A Law and Economics Approach to the Regulation of Attorneys and Physicians in the US, Belgium, the Netherlands, Germany and the UK, Antwerpen, MAKLU, 1993, 195-224.

46 Oudshoorn, C., "Omgevingsveranderingen, systeemkosten en institutionele vernieuwing: een essay over nieuwe institutionele evenwichten", Research Memorandum 9701, Research Centre for Economic Policy, Erasmus University Rotterdam, 45-49. 
full coverage of medical services will lead to the problem that neither patients nor physicians (or other providers of health care for that matter) have any incentive to examine, for instance, how services can be provided at the lowest price. Therefore, the price of medical services will often be regulated to cope with this problem ${ }^{47}$. This, however, does not solve the problem of the optimal choice between various methods of treatment with different (regulated) prices. It obviously goes beyond the scope of this paper to deal with the issue of the regulation of health care services in detail. One should only be aware of the fact that through informational asymmetry the providers of services have the advantage that they can determine themselves what kind of services a patient needs, which may well depend upon the price of the particular service. Hence, health care reform should also address the question of how various regulatory and funding schemes influence the incentives of the providers of medical care. In this respect it is sometimes mentioned in the literature that health care expenses are influenced by a three-player triangle, composed of the patient as demander of care, the providers of care on the supply side, and the compensation institution (private insurance or social security). Hence, the law should give incentives to all three players involved to reach an optimal provision of health care at competitive prices ${ }^{48}$.

\section{Intermezzo: some crucial questions and trade-offs in health care reform}

The basic question that we started off with was whether support can be found in the law and economics literature on insurance to introduce instruments that may achieve a cost reduction in health care, which is one of the crucial questions in the current health care reform debate. This led us to look at two options, asking the question whether social insurance systems can benefit from the introduction of the principles of private insurance or whether the principles of social insurance can still be applied if, through deregulation or privatisation, policy makers turned to the market for health care insurance.

In the overview provided above we found that a few crucial questions have to be asked in that respect:

1. First, no matter what kind of system of financing health care is installed, the question arises whether the traditional remedies against moral hazard, either controlling the insured party through risk differentiation or partially exposing the insured party to risk (through an upper limit or a deductible) can still be applied.

These remedies may conflict with principles of social insurance, such as the solidarity between good risks and bad risks, which is obviously contrary to a system of risk

${ }^{47}$ Arrow, K., l.c., 962. See also Von der Schulenburg, J.M., "Regulatory Measures to Enforce Quality Produc-tion of Self-Employed Professionals - a Theoretical Study of a Dynamic Market Process", in Von der Schu-lenburg, J.M. and Skogh, G., (eds.), Law and Economics and the Economics of Legal Regulation, Boston, Kluwer, 1986, 133-147.

${ }^{48}$ We cannot discuss this literature within this paper; see, for example, Ellis, R.P. and McGuire, T., "Optimal Payment Systems for Health Services", Journal of Health Economics, 1990, vol. 9 (4), 375-396; Ellis, R. and McGuire, T., "Supply Side and Demand Side Cost Sharing in Health Care", Journal of Economic Perspectives, 1993, vol. 7, 135-151; Ellis, R. and McGuire, T., "Hospital Response to Prospective Payment: Moral Hazard, Selection and Practice Style Effects", Journal of Economic Perspectives, 1996, vol. 15, 257-278. 
differentiation. Some policy implications may, however, be deduced from this literature on the necessity to control moral hazard.

One implication is that if the policy maker wishes to rely to a larger extent on private market insurance to cover health risks, risk differentiation will be inevitable. The question arises whether this will then necessarily lead to a conflict with the principles of social insurance. It seems not feasible to effectuate income redistribution with private health care insurance unless a system of strict (premium) regulation could be established. There could be solidarity between bad and good risks, even in private insurance. In that case the insurer could charge a flat premium which would cover future risks. If this only covered risks where the demand does not increase with the price, there would not be a moral hazard problem or it would be so small that it could be controlled through a deductible. It is therefore theoretically possible to imagine private insurance with solidarity between bad and good risks, but it does not seem possible to imagine private insurance which would go one step further and achieve income redistribution as well.

Equal access to health care services can still be guaranteed with private insurance if those risks which cannot be covered on the private market are somehow taken care of. A duty on the part of the insurer to accept these risks does not seem to be the optimal solution; the remainder could be taken care of either through government provided insurance or through a provision of health care free of charge for that category. Obviously within such a system there will also be a redistributive element, since this remainder category will have to be financed somehow.

The moral hazard literature may also have implications for social insurance. If the demand for certain health care services indeed depends upon the price charged, moral hazard can be controlled either with a deductible or through an upper limit on reimbursement. These ways of avoiding moral hazard remain possible even if the premium charged is income dependent and risk differentiation is, therefore, not possible via differentiation of premiums. The ques-tion of whether risks are dependent upon the price charged is of course an empirical one and may largely depend upon the nature of the particular risk. The desirability of avoiding moral hazard in social insurance will, therefore, largely depend upon the nature of the particular risk.

2. Such a differentiation between the nature of the risks at stake is also useful in answering the question of the desirability of compulsory insurance. Addressing this question from the attitude towards risk and the information differences, there is a strong case in favour of compulsory insurance, at least for the high risks. If one assumes that information is also lacking on smaller risks, there may be a case for compulsory insurance for these smaller risks as well. This could also be defended as a device to lower transaction costs.

3. Even if there is, hence, a strong case for compulsory insurance this does not necessarily mean that this compulsory insurance should be government provided. It can to a large extent be provided by private insurers, provided that the remainder category which cannot rely on the private market for insurance is somehow taken care of. Care should be taken to discourage overdemand within this remainder category and to control access to this category strictly. 
4. As far as the question is concerned of whether this compulsory insurance should be provided through private insurance or through social insurance, the answer will of course be different if redistributive goals have to be achieved as well, as they may be difficult to meet through private market insurance. Hence, this inevitably implies a normative choice of goals for a health care scheme.

5. Finally, we showed that within the health care reform debate attention should also be paid to the incentives of the providers of care.

This brief summary of the previous sections shows that health care insurance can to a large extent also be guaranteed through the private market. To some extent the principles of social security such as equal access can be guaranteed with private insurance as well provided the "remainder risks" are somehow taken care of. Within the scope of this paper we cannot discuss the efficiency of income distribution via social security 49 . For this paper it is only important to note that income redistribution can be achieved more efficiently through regulation than through private market insurance.

\section{Legal implications}

\subsection{Some conventions}

After this brief economic analysis, it is equally interesting to examine whether it would be possible to reform a health care system so that it would rely more on insurance economics principles, such as risk differentiation and relating the premium to the magnitude of the risk, instead of on the traditional solidarity and income redistributive demands of social security systems. In this respect it must be mentioned that many countries which are now contemplating reforming their health care systems are bound by international agreements which lay down provisions stipulating a minimum guarantee which signatory states have to provide. Most of these conventions emerged through the international labour conference, the predecessor of the current International Labour Organisation (ILO), a specialized institution of the United Nations ${ }^{50}$. Some conventions are of a more recent date, such as the European Social Charter, which equally lays duties on its member states to guarantee a minimum level of social security to their citizens.

The question, therefore, arises of whether these economic principles are compatible with (some of) the provisions of these conventions. One should indeed not forget that most of these conventions were negotiated either at the end of the $1920 \mathrm{~s}$ or in the $1960 \mathrm{~s}$, in a time-frame where, for instance, guaranteeing a minimum income in case of disability through mandatory insurance was considered highly important, given the experience of the recession in the 1920s. Some have, however, asked whether these conventions still fit

${ }^{49}$ See generally on the economics of income redistribution, for example, Stigler, G., "Director's Law of Public Income Redistribution", Journal of Law and Economics, 1970, 1-10; Tullock, G., Economics of Income Redistribution, Boston, Kluwer, Nijhoff, 1983 and Johnson, W., "Income Redistribution as Human Capital Insurance", Journal of Human Resources, 1987, 269-280 and with respect to social security: Olson, M., "Why Some Welfare-State Redistribution to the Poor is a Great Idea", in Rowley, Ch., (ed.), Democracy and Public Choice; Essays in Honor of Gordon Tullock, Oxford, Blackwell, 1987, 191-222.

50 The principles underlying the ILO Conventions are discussed in detail in the dissertation by Boonstra, K., The ILO and the Netherlands, Leiden, NJCM, 1996. 
the needs of society today. The legal community in the Netherlands was shocked when the possibility of the Netherlands withdrawing from ILO Convention 131 with respect to minimum wages was discussed ${ }^{51}$. During the recent health care reform debate in the Netherlands it was also mentioned that some of the proposals to deregulate the health care system violate international duties as laid down in the ILO Conventions ${ }^{52}$. Hence, it seems important to look briefly at the most important demands of these international conventions. Obviously, it is not possible within the limited scope of this paper to discuss all these conventions in detail; we shall focus on two ILO Conventions and on the European Social Charter ${ }^{53}$.

\subsection{ILO Conventions 24 and 25}

Two important conventions with respect to insurance are those concerning sickness insurance for workers in industry and commerce and domestic servants ${ }^{54}$ and concerning sickness insurance for agricultural workers ${ }^{55}$. Both where promulgated on 15 June 1927. These conventions do not contain a generalized system of protection for all citizens or employees, but are only applicable to certain categories of employees such as workers in industry or agricultural workers. As far as the structure is concerned, the conventions show similarities. According to article 1 of both treaties, the ratifying states must introduce a system of compulsory sickness insurance for the specific category of employees to which the convention is applicable ${ }^{56}$. This means that for agricultural workers, workers in industry and commerce and for domestic servants there must be a system of compulsory insurance against illness. The conventions also contain provisions on financing the health care system. Article 7, section 1, stipulates that the insured parties (employees) and their employers shall share in providing the financial resources of the health care insurance system. This means that a contribution is witheld from the wages of the employee to pay for his sickness insurance, which is increased by the amount the employer pays himself. Therefore, both the principle that there should be mandatory insurance and the financing of it through contributions from the employee and the employer are laid down in the conventions. Moreover, it is also stipulated who should provide health care insurance.

According to article 6.1 sickness insurance shall be administered by self-governing institutions, which shall be under the administrative and financial supervision of the competent public authority and shall not be carried on with a view to profit. Apparently this refers to the health care institutions such as the Dutch and the Belgian health care funds, which are formally autonomous, but are subject to administrative control by the public authorities and indeed, in principle, do not aim to make a profit. However, article

\footnotetext{
${ }^{51}$ Jacobs, A., "Opzegging van IAO-Verdrag 131", NJB, 1993, 1147-1149.

${ }^{52}$ See De Wolff, D., "Internationaal recht verbiedt privatisering ziektewet", $N J B, 1993,1517$.

${ }^{53}$ The possibilities to privatise social security have been extensively tested to the international conventions by Van der Heijden, P.F., "Privatisering van de sociale zekerheid: begrensd door (internationale) sociaalrechtelijke normen", in Fase, W.J.P.M., e.a., Sociale zekerheid: privaat of publiek?, 58-72, who also incorporates European law (and directives) into his analysis.

${ }^{54}$ ILO Convention number 24, Tractatenblad, 1957, number 27.

${ }_{55}^{5}$ ILO Convention number 25, Tractatenblad, 1957, number 28.

${ }^{56}$ Article 1 of the convention provides that each member of the international labour organisation ratifying the convention undertakes the obligation to set up a system of compulsory sickness insurance which shall be based on provisions at least equivalent to those contained in this convention.
} 
6.1 also provides for the possibility of health care insurance via the private market, since article 6.1 in fine provides: "Institutions founded by private initiative must be specially approved by the competent authority". From this it seems to follow that compulsory health care insurance could be provided through private insurance, if prior approval had been given ${ }^{57}$. Finally article 6.3 also provides that the administration of sickness insurance may, nevertheless, be undertaken directly by the state where and as long as its administration is rendered difficult or impossible or inappropriate by reason of national conditions and particularly by the insufficient development of the employers' and workers' organisations.

The system of these two conventions is, therefore, quite straightforward. For the categories of workers to whom the convention is applicable the signatory state should take care of compulsory health care insurance, but the way this health care insurance system is organised is optional. It can be provided through:

- self-governing institutions under the administrative and financial supervision of the competent public authorities;

- institutions founded by private initiative;

- sickness insurance directly organised by the state.

From this it follows that the signatory state is allowed to award the organisation of sickness insurance to private initiative on condition that the state itself is also prepared to act as insurer for those cases where other types of insurance are impossible or inappropriate by reason of national conditions. Here one may recall the situation where individuals cannot receive insurance through the (self-governing) institutions or "institutions founded by private initiative". Thus article 6 guarantees that for the categories of employees to which the convention is applicable it can put into effect the principle of compulsory sickness insurance which is laid down in article 1 of the convention.

The conventions hence stipulate to whom the compulsory sickness insurance system applies and how sickness insurance shall be administered. In addition, there are also provisions indicating what kind of health care services should be provided within this compulsory sickness insurance scheme. Article 4.1 provides that the insured person shall be entitled free of charge, as from the commencement of his illness and at least until the period prescribed for the grant of sickness benefit expires, to medical treatment by fully qualified medical personnel and to the supply of proper and sufficient medicines and appliances. Hence, there is in principle a right to medical treatment and a right to free medication. This rather exhaustive provision is, however, tempered in article 4.2 which provides that nevertheless, the insured person may be required to pay such part of the cost of medical benefit as may be prescribed by national law or regulation. So article 4 grants a right to the insured to free medical treatment and medication which can be administered through the compulsory sickness insurance scheme provided according to article 6 . It is unclear whether article 4 allows for a system of restitution, whereby the insured would first have to pay the bills himself, but would be able to reclaim on the basis of the insurance

${ }^{57}$ The not-for-profit condition relating to the self-governing institutions does not seem to apply to institutions founded by private initiative. 
cover. One could argue that in such a case medical treatment is still provided "free of charge" as required in article 4.1. However, this does not appear to comply with the spirit of the convention which seems to require direct and unconditional medical treatment of the insured patient. Hence, article 4 seems to grant this right to the patient also in cases where he cannot pre-pay the doctor's bill before this is reimbursed by his insurer. It is important to stress that article 4.2 gives national states which ratify the convention the possibility of introducing a deductible. National laws or regulations are to determine the precise amount of this contribution. However, article 4.2 mentions a "part of the cost of medical benefit", which seems to imply that this part may not be so large that it would in fact deny the principle of the right to medical treatment free of charge as defined in article 4.1.

As far as the financing of the system is concerned, article 7 of the convention concerning sickness insurance for workers in industry provides, as we indicated above, that all the insured persons and their employers are to share in providing the financial resources of the sickness insurance system.

\subsection{The European Social Charter and $1 L O$ Convention 102}

Similar provisions can be found in other conventions. We could, for example, indicate the convention concerning minimum standards of social security, which was also drafted by the general conference of the international labour organisation ${ }^{58}$ and the European Social Charter, promulgated in Torino on 18 October 1961. An important difference between the ILO conventions which we have just discussed and these conventions is that the previously discussed ILO conventions are merely applicable to a certain category of employees. The scope of protection of the European Social Charter and the convention concerning minimum standards of social security is, however, much wider. The European Social Charter grants a right to social security in article 12. As far as the contents and minimum standards of this social security system are concerned, the European Social Charter refers in article 12.2 to "a satisfactory level at least equal to that required for ratification of the International Labour Convention" 59 . Hence, these conventions can be discussed simultaneously. The European Social Charter contains a few broadly defined rights which have to be respected by the ratifying states. In this respect, for instance, article 11 is important. It stipulates:

"everyone has the right to benefit from any measures enabling him to enjoy the highest possible standard of health attainable".

Moreover, in this article 11 the ratifying states also agree to take the necessary measures:

"1. to remove as far as possible the causes of ill health;

2. to provide advisory and educational facilities for the promotion of health and the encouragement of individual responsibilities in matters of health;

3. to prevent as far as possible epidemic, endemic and other diseases".

${ }^{58}$ Convention number 102 accepted by the International Labour Conference during its 35 th session, Geneva, 28 June 1952.

${ }^{59}$ No. 102 Concerning Minimum Standards of Social Security. 
Furthermore, we already indicated that article 12 of the European Social Charter provides everyone with a right to social security, which refers to ILO Convention 102 concerning minimum standards of social security.

Another provision which is of importance within the European Social Charter is article 13 which provides for a general right to medical assistance for anyone who does not have the financial resources to insure himself. To guarantee this right the signatory states are forced:

"1. to ensure that any person who is without adequate resources and who is unable to secure resources either by his own efforts or from other sources, in particular by benefits under a social security scheme, be granted adequate assistance, and, in case of sickness, the care necessitated by his condition".

Hence, this European Social Charter provides an important duty for the signatory states to guarantee that medical assistance is also provided for in case of insolvency.

We already indicated that the European Social Charter refers to the provisions contained in ILO Convention 102 concerning minimum standards of social security. According to this convention specific protective measures are applicable to specific categories of protected persons. Article 9 of this convention determines the classes of protected individuals as follows:

“a. prescribed classes of employees, constituting not less than $50 \%$ of all employees, and also their wives and children; or

b. prescribed classes of the economically active population, constituting not less than $20 \%$ of all residents and also their wives and children; or

c. prescribed classes of residents, constituting not less than $50 \%$ of all residents".

According to article 10 of the convention these protected persons shall be granted specific benefits, which shall include at least:

"a. in case of a morbid condition;

(i) general practitioner care, including domiciliary visiting;

(ii) specialist care at hospitals for in-patients and out-patients, and such specialist care as may be available outside hospitals;

(iii) the essential pharmaceutical supplies as prescribed by medical or other qualified practitioners; and

(iv) hospitalisation where necessary; and

b. in case of pregnancy and confinement and their consequences;

(i) pre-natal confinement and post-natal care either by medical practitioners or by qualified midwives; and

(ii) hospitalisation where necessary".

The European Social Charter obviously places further obligations on the signatory states, such as the duty to provide health care to those who cannot afford it. Such a duty, however, does not necessarily conflict with the idea that an important role could be played 
by the private insurance market in providing health care insurance. This would indeed only imply that for those risks for which the private insurance market cannot provide cover - because of insolvency, for instance - state intervention guaranteeing health care free of charge would be necessary.

There are, however, within the provisions of the European Social Charter also possibilities of construing the health care insurance system in an incentive-based manner. Article 10.2 of the European Social Charter indeed provides that the beneficiary or his breadwinner may be required to share in the cost of the medical care the beneficiary receives in respect of a morbid condition. Hence, some kind of incentive through, for example, a deductible or other form of contribution, is still possible. However, article 10.2 in fine provides: "the rules concerning such cost-sharing shall be so designed as to avoid hardship".

\section{Legal versus economic analysis}

The question arises of how the principles seen in these conventions align with some of the economic points as summarised in Section 7, especially with respect to the question of whether these conventions allow either a privatisation of health care insurance or a social insurance system which is more incentive based.

The brief overview of the conventions provided in Section 8 shows that they contain many provisions that a legislator in a country which ratified these conventions would have to take into account in a health care reform debate ${ }^{60}$.

Generally these provisions do not seem to constitute a serious threat if the policy makers want to rely increasingly heavily on an incentive-based health care insurance system. Summarising, the most important principles underlying the conventions are:

1. A compulsory sickness insurance scheme must be installed. This might be inefficient for some low risks. However, the existence of information deficiencies and the lower transaction costs that a compulsory scheme would bring, could justify compulsory insurance.

2. Compulsory insurance may be administered by self-governing institutions or by institutions founded by private initiative. Private health care insurance is, hence, not excluded.

3. The premium must be paid by both the insured persons and their employers. However, this in no way implies that there should necessarily be an income-dependent premium.

4. All conventions apparently still allow either an upper limit on reimbursement or a deductible. So even if one reads the conventions in such a way that the premium has to

60) Obviously there are many more international legal norms, more specifically Euro-pean directives that should be taken into account in the health care reform debate. We could not discuss these within the scope of this paper. See on the European dimension of the health care debate, McKee, M., "The Influence of Europe on National Health Policy", in Gunning-Schepers, L.J., Kronjee, G.J. and Spasoff, R.A., (eds.), Fundamental Questions About the Future of Health Care, The Hague, SDU, 1996, 217-239. 
be income dependent ${ }^{61}$, moral hazard can be remedied by partially exposing the insured party to risk.

5. Equal access to basic medical assistance is to be guaranteed even to those who cannot afford it. Hence, if there is private market insurance, the state would somehow have to guarantee that even those who cannot purchase insurance cover can receive basic medical treatment.

The conventions do therefore allow compulsory sickness insurance to be provided to a large extent by private insurance companies. Some commentators do, however, argue that a total privatisation of health care insurance would conflict with the conventions ${ }^{62}$.

Summarizing, a state wishing to shift to a more incentive-based health care insurance system does not necessarily have to revoke the conventions discussed above.

\section{Concluding remarks}

In the introduction we stated that in many countries health care schemes are under intense pressure to reform ${ }^{63}$. There seems to be a general feeling that the luxury of generous health care systems is not affordable any longer. This prompts the question of whether the system can be reformed in such a way that incentives for cost reduction are given. It is important to stress that to a large extent some legal systems already do rely heavily on the incentives for cost reduction prescribed by economic analysis. Within the scope of this paper we have only tried to add to the health care reform debate by recalling the basic principles and questions which may be of importance during this debate, without any attempt being made to answer those questions.

We merely tried to indicate that there may be benefits in using the law and economics literature on insurance in the current health care reform debate. One potential benefit is that the economic literature on private insurance may be useful to indicate how social insurance can become more incentive based. A comparison between the two systems can also show that there are totally different principles underlying private and social insurance. These differences should be taken into account, for example, when the privatisation of social insurance in the form of private health care insurance is advocated. Incomedependent premium setting then becomes difficult and premiums should in principle be related to risk to provide a reserve for future claims. Unlike the case of social insurance, private insurers cannot rely on governments to cope with their deficits. If they do not relate premiums to risk they may be subject to the market sanction, i.e. they may go bankrupt.

Although it is certainly true that private and social insurance start from different angles, they seem to influence each other mutually as well. The principle of equal access to health care services underlying the social security system is obviously not carried through

61 Which is not at all provided for in the conventions.

62 Van der Heijden, P.F., l.c., 70-72; he then more specifically refers to the duty to provide medical treatment also to those who cannot afford it.

63 This is the tendency referred to by Vinke as the "decollectivization" of the social security system (Vinke, H., o.c., 167-182). 
all the way. There certainly is equal access for basic medical needs, but in most countries individuals can purchase additional coverage according to their own demands and pay a corresponding premium. Also the principles of private insurance cannot be carried through in all respects. Cousy has discussed the ethics of insurance companies which may lead them to accept some solidarity between good and bad risks and not carry out risk differentiation in a very detailed way ${ }^{64}$. Wils has also pointed out that detailed risk differentiation may conflict with basic human rights if, for example, risks are differentiated according to gender or sexual preferences ${ }^{65}$. We also indicated that even if health care insurance is provided by the private market, there has to be some kind of a guarantee, either through direct provision or through insurance, that the category of people who cannot purchase insurance on the regular market is taken care of as well. How such a universal provision of insurance should be taken care of in practice clearly merits further research.

Obviously, on the subject of the trade-off between market and regulatory solutions one must take empirical research into account as well. If incentive-based mechanisms within health care insurance are advocated, the crucial question arises of what kind of risks can in fact be influenced by the price charged. A health care reform should, of course, take empirical evidence in that respect into account. In addition, the choice between a market or regulation implies an important normative component as well. An income-dependent premium will be hard to combine with insurance economics principles of risk differentiation. Therefore, the policy maker should be aware of the fact that if income redistributive goals have to be achieved through the financing of the health care system there may be a price to be paid as far as the efficiency of the system is concerned. The fact that many of the existing social security schemes have a redistributive component will inevitably lead to political pressures not to take these "rents" away, which might make changes difficult ${ }^{66}$.

Finally, we wish to indicate the fact that there is often no need to make a strict choice between market or government provided insurance. Some commentators have advocated solutions in the form of a combination of a limited social insurance scheme providing basic medical treatment, financed by income-dependent premiums, with the possibility of purchasing additional insurance on the market according to the preferences and demands of the particular individual ${ }^{67}$. Such a combined system could consist of compulsory social

${ }^{64}$ Cousy, H.A., "Lectuurnotities en reflecties over ethiek in het zakenleven, in het bijzonder in de verzekeringen", in Fleerackers, F., (ed.), Mens en recht. Essays tussen rechtstheorie en rechtspraktijk, Liber Amicorum Jan M. Broekman, Peeters, 1996, 47-63.

${ }^{65}$ Wils, W.P.J., "Insurance Risk Classifications in the EC: Regulatory Outlook", Oxford Journal of Legal Studies, 1994, 449-467.

66 We could not incorporate public choice aspects of social security into this paper. See in that respect, for example, Bowles, R. and Jones, Ph., "Medical Indemnity Insurance in the UK: A Public Choice Approach", Geneva Papers on Risk and Insurance, 1990, 27-40; Buchanan, J., The Inconsistencies of the National Health Service, London, Institute of Economic Affairs, occasional paper no. 7, 1964; Gustafsson, B.A. and Klevmarken, N., (eds.), The Political Economy of Social Security, Amsterdam, North-Holland, 1989 and Anderson, M., Welfare, the Political Economy of Welfare Reform in the United States, Stanford, Hoover Press, 1978.

${ }^{67}$ See Van Mierlo, J.G.A., "Hervorming van het Nederlandse stelsel van sociale zekerheid: financiële consequenties en politieke haalbaarheid", in Van den Bosch, F.A.J. and Peterson, C. 
insurance for the larger risks where moral hazard does not play an important role and the possibility of private insurance for the smaller risks. To guarantee equal access in order to comply with the conventions, the latter could be supplemented by government-provided insurance or direct care for those cases where private markets consider the risks uninsurable.

(Eds.), Economie en arbeidsongeschiktheid: analyse en beleid, Deventer, 1983, 215-241. This is also defended by De Kam, C.A., I.c., 52-57. The possibilities of complementary health care insurance in addition to a basic social benefit system are also addressed, for example, by Cousy, in "De rol van de private verzekeringen in de aanvullende sociale verzekeringen: de regels van het spel", in Van Langendonck, J. (ed.), Liber Amicorum Roger Dillemans, Kluwer, Antwerp, 1997, 55-74. 


\section{REFERENCES}

AARON, H., "Issues Every Plan to Reform Health Care Financing must Confront", Journal of Economic Perspective, 1994, vol. 3, 31-43.

AKERLOF, G., "The Market for "Lemons": Quality, Uncertainty and the Market Mechanism", Quarterly Journal of Economics, 1970, 488-500.

ANDERSON, M., Welfare, the Political Economy of Welfare Reform in the United States, Stanford, Hoover Press, 1978.

ARROW, K., "Uncertainty and the Welfare Economics of Medical Care", American Economic Review, 1963, 941-973.

ARROW, K., Aspects of the Theory of Risk-Bearing, Helsinki, Yrjö Johnsonin Säätiö, 1965.

BOONSTRA, K., The ILO and the Netherlands, Leiden, NJCM, 1996.

BORCH, K., "The Utility Concept Applied to the Theory of Insurance", The Astin Bulletin, Vol. 1, 1961, 245-255.

BOWLES, R. and JONES, Ph., "Medical Indemnity Insurance in the UK: A Public Choice Approach", Geneva Papers on Risk and Insurance, 1990, 27-40.

BUCHANAN, J., The Inconsistencies of the National Health Service, London, Institute of Economic Affairs, occasional paper No. 7, 1964.

COUSY, H.A., "Lectuurnotities en reflecties over ethiek in het zakenleven, in het bijzonder in de verzekeringen", in Fleerackers, F., (ed.), Mens en Recht. Essays tussen rechtstheorie en rechtspraktijk, Liber Amicorum Jan M. Broekman, Peeters, 1996, 47-63.

COUSY. H., "De rol van de private verzekeringen in de aanvullende sociale verzekeringen: de regels van het spel", in Van Langendonck, J. (ed.), Liber Amicorum Roger Dillemans, Kluwer, Antwerp, 1997, 55-74.

DE KAM, C.A., "Privatisering van sociale zekerheid: een werkbaar alternatief?" in Fase, W.J.P.M., e.a., Sociale zekerheid: privaat of publiek?, Deventer, Kluwer, 1994, 36-48.

DEN HERTOG, J., "An Economic Analysis of the (Self-)Regulation of Physicians in the Netherlands", in Faure, M., Finsinger, J., Siegers, J. and Van den Bergh, R. (eds.), Regulation of Professions. A Law and Economics Approach to the Regulation of Attorneys and Physicians in the US, Belgium, the Netherlands, Germany and the UK, Antwerpen, MAKLU, 1993, $195-224$.

DE WOLFF, D., "Internationaal recht verbiedt privatisering ziektewet”, NJB, 1993, 1517.

DIJKSHOORN, M.W., "Ontwikkelingen in de WAO", Verzekeringsarchief, 1996, 82-86.

EHRLICH, J. and BECKER, G., "Market Insurance, Self Insurance and Self Protection", Journal of Political Economy, 1972, 623-648.

ELLIS, R.P. and MCGUIRE, T., "Optimal Payment Systems for Health Services", Journal of Health Economics, 1990, vol. 9 (4), 375-396.

ELLIS, R. and MCGUIRE, T., "Supply Side and Demand Side Cost Sharing in Health Care", Journal of Economic Perspectives, 1993, vol. 7, 135-151.

ELLIS, R. and MCGUIRE, T., "Hospital Response to Prospective Payment: Moral Hazard, Selection and Practice Style Effects", Journal of Economic Perspectives, 1996, vol. 15, 257-278.

FASE, W.J.P.M., "Privatisering of toch maar aanpassen?", in Fase, W.J.P.M., e.a., Sociale zekerheid: privaat of publiek?, Deventer, Kluwer, 1994, 86-87. 
FAURE, M. and VAN DEN BERGH, R., "Compulsory Insurance for Professional Liability", The Geneva Papers on Risk and Insurance, 1989, 308-330.

FAURE, M. and VAN DEN BERGH, R., "Invloed van verzekering op de civiele aansprakelijkheid: een rechtseconomische analyse", in De invloed van verzekering op de civiele aansprakelijkheid, preadviezen uitgebracht voor de Vereniging voor Burgerlijk Recht, Lelystad, Vermande, 1990, 953.

FAURE, M. and VAN DEN BERGH, R., "Het toelaten van kartels op de Europese verzekeringsmarkt: hogere premies, lagere kwaliteit en meer ongevallen?", NJB, 1993, 261-267.

FAURE, M., FINSINGER, J., SIEGERS, J. and VAN DEN BERGH, R. (eds.), Regulations of Professions. A Law and Economics Approach to the Regulation of Attorneys and Physicians in the US, Belgium, the Netherlands, Germany and the U.K., Antwerp, Maklu, 1993.

FAURE, M. and VAN DEN BERGH, R., "Restrictions of Competiti-on on Insurance Markets and the Applicability of EEC Antitrust Law", Kyklos, 1995, 65-85.

FAURE, M. and HARTLIEF, T., "Towards an Expanding Enterprise Liability in Europe? How to Analyze the Scope of Liability of Industrial Operators and their Insurers", Maastricht Journal of European and Comparative Law, 1996, 235-270.

FENN, P., "The Law and Economics of the Misconduct Rule of Unemployment Insurance", in Burrows, P. and Veljanovski, C.G., (eds.), The Economic Approach to Law, London, Butterworth, 1981, 307-319.

FRANK, R., "Lessons from the Great Battle: Health Care Reform, 1992-1994", Arch. Phys. Med. Rehabil, 1997, 120-124.

FEREJOHN, J. and SHIPAN, Ch., "Congressional Influence on Bureaucracy", Journal of Law, Economics \& Organization, Vol. 6, 1990, 1-20.

FUCHS, V., "From Bismarck to Woodcock: the "Irrational" Pursuit of National Health Insurance", Journal of Law and Economics, 1976, 347-359.

GARRAT, R. and MARSHALL, J., "Supplemental Health Insurance", in Heremans, D. and Cousy, H., (eds.), Essays in Law and Economics III, Financial Markets and Insurance, Antwerp, Maklu, 1996, 225-241.

GUSTAFSSON, B.A. and KLEVUMARKEN, N., (eds.), The Political Economy of Social Security, Amsterdam, North-Holland, 1989.

JACOBS, A., "Opzegging van IAO-Verdrag 131", $N J B, 1993,1147-1149$.

JOHNSON, W., "Choice of Compulsory Isurance under Adverse Selection", Public Choice, 1977, 2325.

JOHNSON, W., "Income Redistribution as Human Capital Insurance", Journal of Human Resources, 1987, 269-280.

KERKHOFF, A.H.M., "The Physicians' Fraternity: Safeguard for Quality or Cartel?", in GunningSchepers, L.J., Kronjee, G.J. and Spasoff, R.A., (eds.), Fundamental Questions About the Future of Health Care, The Hague, Netherlands Scientific Council for Government Policy, 1996, 109-119.

LE BLANC, L.J.C.M., "Bismarck als benchmark. Enkele rechtseconomische beschouwingen over publie-ke sector en sociale zekerheid in Nederland", Ars Aequi, 1990, 654-659.

MACKAAY, E., Economics of Information and the Law, Boston, Kluwer, 1982.

MCKEE, M., "The Influence of Europe on National Health Policy", in Gunning-Schepers, L.J., Kronjee, G.J. and Spasoff, R.A., (eds.), Fundamental Questions About the Future of Health care, The Hague, SDU, 1996, 217-239. 
MITCHELL, O. and ZELDES, S., Social Security Privatization: A Structure for Analysis, National Bureau of Economic Research, Working Paper 5512, Cambridge, 1996.

NEWHOUSE, J., "Reimbursing Health Plans and Health Providers: Selection versus Efficientcy in Production", Journal of Economic Literature, 1996, vol. 34, 1236-1263.

OLSON, M., "Why some Welfare-State Redistribution to the Poor is a Great Idea", in Rowley, Ch., (ed.), Democracy and Public Choice; Essays in Honor of Gordon Tullock, Oxford, Blackwell, 1987, 191-222.

OUDSHOORN, C., "Omgevingsveranderingen, systeemkosten en institutionele vernieuwing: een essay over nieuwe institutionele evenwichten", Research Memorandum 9701, Research Centre for Economic Policy, Erasmus University Rotterdam, 45-49.

PAULY, M., "The Economics of Moral Hazard: Comment", American Economic Review, 1968, 531545.

PAULY, M., "Overinsurance and the Public Provision of Insurance: The Roles of Moral Hazard and Adverse Selection", Quarterly Journal of Economics, 1974, 44-62.

PAULY, M., "Taxation, Health Insurance and Market Failure in the Medical Economy", Journal of Economic Literature, 1986, 629-675.

PAULY, M., "Competition in Health Insurance Markets", Law and Contemporary Problems, 1988, 237-271.

PIETERS, D., Introduction into the Basic Principles of Social Security, Boston, Kluwer, 1993.

PIETERS, D., (ed.), Introduction into the Social Security Law of the Member States of the European Community, Antwerp, Maklu, 1993.

ROTHSCHILD, M. and STIGLITZ, J., "Equilibrium in Competitive Insurance Markets: an Essay on the Economics of Imperfect Information", Quarterly Journal of Economics, 1976, 629-649.

SCHWARTZ, A. and WILDE, L., "Intervening in Markets on the Basis of Imperfect Information: a Legal and Economic Analy-sis", University of Pennsylvania Law Review, 1979, 630-682.

SHAVELL, S., "On Moral Hazard and Insurance", Quarterly Journal of Economics, 1979, 541-562.

STIGLER, G., "Director's Law of Public Income Redistribution", Journal of Law and Economics, 1970, 1-10.

TULLOCK, G., Economics of Income Redistribution, Boston, Kluwer, Nijhoff, 1983.

VAN DE GRIENDT, W., "De Amerikaanse paradox", Sociaal bestek, 1995 (7/8), 9-12.

VAN DER HEIJDEN, P.F., "Privatisering van de sociale zekerheid: begrensd door (internationale) sociaalrechtelijke normen", in Fase, W.J.P.M., e.a., Sociale zekerheid: privaat of publiek?, 58-72.

VAN MIERLO, J.G.A., "Hervorming van het Nederlandse stelsel van sociale zekerheid: financiële consequenties en politieke haalbaarheid", in Van den Bosch, F.A.J. and Peterson, C. (Eds.), Economie en arbeidsongeschiktheid: analyse en beleid, Deventer, 1983, 215-241.

VAN MIERLO, J.G.A., "Een alternatief voor het Plan-Simons? Overwegingen vanuit de welvaartstheorie", ESB, 1991, 1164-1166.

VAN STEENBERGE, J., KLOSSE, S. and DE LEEDE, L.J.M. (eds.), Preventie: een solide basis voor sociale zekerheid?, Antwerpen, Maklu, 1994.

VAN WIJNGAARDEN, P.J., VAN DEN HEUVEL, F.G. and VROOMAN, J.C. (eds.), Preventie in de sociale zekerheid, Den Haag, VUGA, 1992.

VAN WIJNGAARDEN, P. and VAN DEN HEUVEL, F., "Privatisering sociale zekerheid ter discussie", Sociaal bestek, 1995, nr. 12, 2-6. 
VINKE, H., Werknemerscompensatie bij beroepsgebonden schade, The Hague, SDU, 1997.

VON DER SCHULENBURG, J.M., "Regulatory Measures to Enforce Quality Production of SelfEmployed Professionals - a Theoretical Study of a Dynamic Market Process", in Von der Schulenburg, J.M. and Skogh, G., (eds.), Law and Economics and the Economics of Legal Regulation, Boston, Kluwer, 1986, 133-147.

WHINSTON, M., "Moral Hazard, Adverse Selection and the Optimal Provision of Social Insurance", Journal of Public Economics, 1983, 49-71.

WILS, W.P.J., "Insurance Risk Classifications in the EC: Regulatory Outlook", Oxford Journal of Legal Studies, 1994, 449-467.

ZECKHAUSER, R., "Medical Insurance: a Case Study of the Trade-off Between Risk Spreading and Appropriate Incentives", Journal of Economic Theory, 1970, 2, 10-26.

ZECKHAUSER, R., "Public Finance Principles and National Health Care Reform", Journal of Economic Perspective, 1994, 55-60. 